\title{
WRITING DESCRIPTIVE TEKS BASED ON "PROMBLEMS BASED INSTRUCTION (PBI) AT X STUDENTS IN SMK TRIATMA JAYA DALUNG
}

\author{
Putu Ayuning January Punia Putri \\ Universitas Warmadewa \\ ayuningjanuary200@yahoo.com
}

Received: 05-04-2018

Revised: 25-04-2018

Accepted: 30-04-2018

\begin{abstract}
This study aims to describe the use of instruction-based instructional model, knowing what kind of error students find in writing descriptive text as well as to to improve students' self confidence in English, especially in descriptive writing writing skill. The sample of this research is class X students of SMK Triatma Jaya Dalung consisting of 25 students. The study was conducted in January and February 2018 from two research cycles. The first cycle for the pretest and the second cycle for posttes. The results of the study found that the application of Problem Based Instruction (PBI) based learning process can improve the writing of paragraphs of argument on Class X SMK Triatma Jaya Dalung. Application of learning with the PBI model can also increase student learning activities. The mistakes often made by the students of class $X$ of SMK Triatma Jaya Dalung in writing descriptive text paragraphs among them in terms of creativity of topic development, in terms of organization that includes the structure of argumentation and in terms of vocabulary selection, language use, and mechanical aspects, the argumentation has several deficiency. Management of learning with the right PBI model can improve the skills of writing paragraphs of descriptive text of students of Class X SMK Triatma Jaya Dalung. First, the PBI model is more fun in learning to write descriptive text paragraphs. Secondly, the PBI model is more effective in writing descriptive text paragraphs because the problems that exist in reading are easier and inspire students in generating ideas. Third, the PBI model can enhance student creativity.
\end{abstract}

Keywords: writing, descriptive text, problem based instruction

\section{INTRODUCTION}

Writing is one of the language skills. Writing is one of the productive activities in four language skills (Tarigan, 2008). This productive activity generally embodies the work of writing. Writing is very important for education because it allows students to think. Learning to write is to learn to think in / in a certain way (Tarigan, 2008). Writing paragraphs of argument is an activity of creating paragraphs whose development patterns are based on arguments or reasons presented by the author. The argument paragraph includes facts, data, and arguments. Mastika on (Ayu \& Darmayanti, 2014) argues that paragraphs of argument (argumentation) is a discussion, criticism, and discussion.

Writing arguments is an activity to create paragraphs whose development patterns are based on arguments or reasons given by the author. The argument paragraph includes facts, data, and arguments. Mastika on (Ayu \& Darmayanti, 2014) argues that paragraphs of argument (argumentation) is a discussion, criticism, and discussion. During this time, the quality of the students' writing of the paragraph argument is low. The low quality can be seen from the content (substance) or weak student argumentation. In addition, paragraphs made by students have a poor sentence structure. Student writing techniques are often not in accordance with the rules of writing. In addition, the diction or choice of words used is wrongly reviewed from the form and the monotony (not varied). Factors of substance, argument, sentence structure, writing technique, and diction are student's writing weakness in class $\mathrm{X}$ SMK Triatma Jaya Dalung.

The problem faced by students in learning to write is very broad and complex, because most students learn to write passively. This is due to several factors. First, students are asked to read the material and write down the main idea in the text related to the topic. Second, students think that learning to write only to know the meaning of new words that they have not known the meaning. Third, school facilities are not used for learning English especially in writing activities, for example: English labs are not used. Based on the above problem, the researcher found some weakness of $\mathrm{X}$ class student in terms of writing skill which become obstacle in writing subject matter. It makes students only want to know the meaning of words they did not know before without trying to find another word or phrase.

With the lack of understanding in the grammar and procedure of writing argumentation in English, the researcher is interested to conduct interviews with $\mathrm{X}$ grade students and observe the teaching and learning process of English at SMK Triatma Jaya which still face weakness in writing skill. The ability to write it did not give good results. When they try to write, they do not know how to write words correctly in English. In addition, students are afraid of making mistakes because of their poor grammar knowledge. This will automatically affect their fluency.

To solved the problem on this research is using the theory such as:

\section{A. Problem Based Instruction}

The Problem Based Instruction has several other names such as Project-Based Teaching, 
Experienced-Based Education, Authentic Learning and Anchored Instruction. Learning Problem Based Instruction is a learning model based on the many problems that require authentic investigation, ie investigations that require real settlement of real problems (Trianto, 2007).

\section{B. Problem-Based Learning Methods In} Descriptive Writing Lessons

Learning descriptive writing is one of learning that requires critical thinking from students. In this case, problem-based learning methods can be useful. This method helps students to develop their thinking ability. In problem-based teaching, students are taught to connect between what they learn with how the knowledge will be utilized or applied in new situations. Students will be taught how to solve a problem.

The core steps of learning descriptive writing using problem-based learning methods are as follows. 1) the teacher proposes a phenomenon or demonstration or story to raise the problem; 2) the student conducts research to collect data used as information related to problem solving and problem solving; 3) students present and conduct discussions related to the results of research problems that exist; 4) students make appropriate works such as reports. Student report in descriptive writing study using problem-based teaching method is in the form of descriptive essay and 5) students together with teachers to evaluate the learning of writing descriptive that has been done.

\section{Evaluation}

Sukardi on (Firdaus, Herpratiwi, \& Rosidin, 2015) Evaluation is a series of processes that determine a condition to know whether a goal has been achieved. The processes in the evaluation activities aim to understand, give meaning, gain, and communicate information to make decisions. (Arikunto, 2013) suggests that evaluation is an activity consisting of two steps, namely measuring and assessing. Measuring is the activity of comparing things with an existing measure. Assessing is the activity of taking a decision on something with good and bad sizes.

Based on the understanding of the experts above, it can be concluded that evaluation is a series of processes to be able to know the achievement of a learning goal. The evaluation process consists of two main points, namely measurement and assessment. Measurement and assessment is a continuous series of activities covering both quantitative and qualitative aspects. Quantitative data obtained through the measurement activities further qualitative assessment conducted, namely the interpretation and consideration to obtain certain information to make decisions.

\section{Evaluation Tool}

(Arikunto, 2013) explains that the tool is something that is used to facilitate a person to perform tasks or achieve goals more effectively, and efficiently. An evaluation tool is something that is used to evaluate something with results like the actual situation. Broadly speaking there are two evaluation tools, namely tests and nontes. The test is a form of assignment or question that must be done by students who are being tested. An essay test is a form of question that demands student answers in the form of a description with their own language. Objective test is a test that asks students to answer briefly, or by choosing an alternative answer that has been provided (Nurgiyantono, Gunawan, \& Marzuki, 2009).

(Nurgiyantono et al., 2009) mentions that nontes evaluation tool is a tool to get information about people who tested without using the test equipment. There are several kinds of techniques nontes, among others are multilevel scale, questionnaires, match list, interviews, observations, and curriculum vitae (Arikunto, 2013). Based on the above description, this study uses the test as a means of evaluation of learning to write an argumentation. Through the test will be obtained by students so that the results obtained useful data to obtain information about students' writing skills.

\section{Characteristics of Descriptive Evaluation Appraisal}

Writing is an activity to express ideas, ideas, and thoughts of someone who uses written language. Through writing tests given to students will be obtained essays containing ideas and thoughts of students who want to be communicated to the reader. To be able to know the quality of the students' writing required appropriate assessment characteristics, which can assess the writing of students. There are several models of assignment assignments. First, the assessment model of writing assignments on a scale of 1-10. Second, the assessment of writing assignments with the weighting of each element. Third, assessment of essay with interval scale model (Nurgiyantono et al., 2009).

Based on the background, there are three issues discussed in this research. The problem is, 1) how is the implementation of instruction-based instruction on the students of Class X SMK Triatma Jaya Dalung ?,2) what kind of mistakes do students do in writing descriptive text on the students of Class X SMK Triatma Jaya Dalung? And 3) how is the improvement of instruction-based instruction on students of Class X SMK Triatma Jaya Dalung?.

\section{METHODS}

This study uses classroom action research (CAR) as a research design. Therefore, this classroom action research will take note of improving students' writing skills through problem based instruction techniques (PBI) using two types of tests: initial reflection (IR) or pre-test and reflection ( $\mathrm{R}$ ) or post test ( after). Initial reflection (IR) is intended to assess pre-existing writing skills, while reflection $(\mathrm{R})$ to be awarded at the end of each session, is intended to reveal the expected 
improvement in student writing achievement once they are taught through instruction. This classroom action research is primarily aimed at knowing the effectiveness of teaching writing through instruction -based instruction. Due to this fact, post test results in cycle I will be used as a useful and basic input to improve planning in cycle II. Therefore, cycle II will begin with a revised plan (RP). It will be anticipated to be much more effective and conducive to cycle I. The effectiveness of teaching writing skills through instruction-based instruction is thought by comparing the average value of the initial reflection or Pre-test (X0) obtained by the subject. With the average value of reflection or post test both in cycle I (X1) and cycle II (X2).

\section{III.DISCUSSION}

\section{A. Application of PBI Learning Model}

Implementation of PBI can improve the writing skill of descriptive paragraph at student of Class X SMK Triatma Jaya Dalung. Application of learning with the PBI model can also increase student learning activities. The improvement of students' skills and learning activities is supported by positive student responses to the application of the PBI model. Management of learning with PBI models that can improve the skills of writing descriptive paragraphs of student descriptive text are: (1) students who are often noisy moved to the front seat by the teacher to avoid noise in the classroom; (2) students are given the opportunity to prepare learning tools before teachers start learning; (3) students are given emphasis to understand the learning objectives; (4) students pay attention to examples of topic sentences, explanatory sentences, and paragraphs of arguments made by teachers; (5) students are emphasized to listen to the teacher's explanation of the steps to write descriptive text paragraphs based on the problem; and (6) students are given the assertion that the making of descriptive text paragraphs on the basis of problems must begin with incentive reading activities.

This study aims to determine 1) To describe the data in this study obtained from the score of cycle I (pre test) to determine the initial ability of students write descriptive text and cycle score II (post test) to determine the final ability of students write descriptive text.

\section{1) Result of Research of Cycle I (Pre Test)}

Based on the observation of the researcher during the first cycle, there are several

things that need to be observed in the application of PBM model in learning to write descriptive text paragraph, among others: (1) there are some activities that students do not optimally, such as listening to perception about reading comprehension, listening the purpose of learning well, listening to teacher explanations on the subject matter, reading the existing reading of the actual issues in it, discussing the issues raised with a friend, making the framework of the paragraphs of descriptive text in the form of a topic sentence, creating a descriptive text paragraph framework in the form of several explanatory sentences, and (2) the students' KKM scores have not been met as a result of poor student behavior. Bad student behavior, such as students do not directly read the reading because they are stunned and engrossed in chatting with their friends so they cannot understand the reading well and the students have not done the thinking process in writing descriptive text paragraphs because of their lack of understanding of the reading.

The number of students who have not completed indicates that the learning in cycle I is not going optimally. That is, students do not have understanding in accordance with the established criteria mastery. Therefore, the application of the PBM pattern to improve the skill of writing argument paragraphs in the next cycle is very important. Another effort by the teacher is to provide a longer and comprehensive reading so as to contain more clear and detailed issues. This will affect the perspective and degree of student criticism. Reflecting from cycle I that the reading material is very short, cycle II will be presented a long enough reading.

\section{2) Results Cycle II (Post Test)}

Learning in cycle II is implemented referring to the action plan generated through reflection at the end of cycle I. Cycle II is designed in a single meeting with a time allocation of $2 \times 40$ minutes. The material taught at the meeting was held on Tuesday, 5 February 2018, ie writing a paragraph of descriptive text with the pattern of PBI. There are several action plans made in cycle II as follows, 1) students who are often noisy moved to the front seat by the teacher to avoid noise in the classroom; 2) students are given the opportunity to prepare learning tools before teachers start learning; students are checked for attendance by teachers; students listen to the apperception delivered by the teacher; 5) the students listen to the learning objectives conveyed by the teacher; 6) students pay attention to examples of topic sentences, explanatory sentences, and descriptive text paragraphs made by the teacher; 7) students listened to teacher's explanation of the steps to write descriptive text paragraphs based on the problem; 8) students listen to teacher affirmations regarding the making of descriptive text paragraphs based on issues that must be preceded by intensive reading; 9) students listen to teacher affirmation of the importance of using the most effective time possible; 10) students read reading that contains problems intensively. Based on data analysis in Cycle I and Cycle II, it can be described as follows. 
a) Cycle I

Based on preliminary observations prior to the applied Problem Based Instruction learning model, it is known that the students' learning outcomes in writing argumentation are still low. This can be seen from the average score of learning test results and the percentage of classical completeness of $52.77 \%$. This is because learners have never been directly involved with learning materials on real life. During this time the teacher has never applied a variety of models, methods and learning approaches. From the information obtained by the researchers that learners are less active in following the learning. And during the course of the learner the learner listens more, writes and does not pay attention to what is explained by the teacher. In addition, learners have difficulty understanding the exact material. So that learners are not eager to follow abstract learning, such as writing argumentation. This shows that in learning to write argumentation student still lazy and less involving student activity, so result learn participant in writing argumentation very less.

In this cycle I learning result of learning new learners raised with Problem Based Instruction learning model. By examining the problem of the results of data analysis of learning outcomes of learners given to learners before the action. From the problems experienced by learners during the previous descriptive writing study, then in the first cycle through the model of Problem Based Instruction learning is expected to improve learning outcomes of learners in descriptive writing.

In cycle $I$ the material presented is about describe favorite idol. Action on learning cycle I by applying Problem Based Instruction learning model. At the beginning of the lesson the teacher conveys the learning objectives. Teachers begin learning by giving motivation to learners and explaining about the dangers of drugs. Teacher asks the learners about the drugs. Then give the learners the opportunity to express what they know related to drugs in everyday life. Then the teacher gives explanations and associate the phenomena that once the natural learners with the material delivered.

With the Problem Based Instruction learning model, make the learner active to write the descriptive text. However, in cycle I, most students are still low in writing about descriptive text. And during the learning process, students are still many who do not pay attention from the teacher's explanation and talk to his friend on the same level. Therefore learners need to be given guidance and motivation so that learners have the spirit to follow the learning of physics subjects.

From the observation activity of learners in following the process of learning Problem Based Instruction, mastery of affective aspects learning in cycle I got the average score of class 64,11 . So it has not fulfilled the specified learning mastery. Students in receiving class activities with attention to explanations, questions or answers of $57.64 \%$, learners who argue / attitude in the discussion $58.33 \%$, the attitude of learners in solving problems $59.03 \%$, learners in expressing ideas to solve problem 45,14\% attitude of learners in cooperating in group 48,61\%. These five aspects have not yet achieved an indicator of success. This is because students are not yet accustomed to express opinions or ideas, questions or arguments because of shame and fear of missteps in delivering it, has not been able to do cooperation between members of the group well.

\section{2) Cycle II}

In cycle II, the material presented is Free Sex among Youth. Learning in cycle II by applying Problem Based Instruction learning model, teachers start learning by giving quiz and motivation with understanding of describing someone or things in our area. Then learners are given the opportunity to ask about the previous material that has not understood. Opportunities are given to other learners to answer or respond to questions from friends. Then the teacher give an explanation and straighten out the inappropriate answers to the learners.

The researcher divided the learner group consisting of 5 group members and distributed group worksheets to each group as well as the learner to write the descriptive text on the worksheet. Learners are directed to write descriptive text according to the steps on the group worksheet. Then learners write their descriptive text about describing someone or things in our area. The observational data obtained by the learners is then recorded in the observation table.

After the descriptive text is finished learners discuss with the group members. The researcher designates one of the groups to present the results of the group discussion to another group. Another group asked questions and gave a rebuttal to the results of the discussions presented. Each group who finished presenting, another group applauded as an appreciation. Then the teacher and the researcher straighten out the learner's correct answers from the discussion and conclude.

Learning on the second cycle by applying the model of Problem Based Instruction learning, learning outcomes learners improved well. From the observation of the students' activity in following the learning process of Problem Based Instruction, the learning comprehension of the affective aspect has increased from the average score of 53.75 in the first cycle to 64.44 in cycle II. So that shows the activities of learners in the learning process cycle II 


\section{RETORIKA: Jurnal Ilmu Bahasa , Vol. 4, No. 1 April 2018, Page 79}

increased but not yet complete learning completeness.

In the second cycle of learners in questioning or answering equal to $68,05 \%$, learners who opinion / attitude in discussion $65,97 \%$, student attitude in solve problem $75,69 \%$, learners in express idea to solve problem 56,94\% attitude of learners in working together in group $55,55 \%$. Of the five aspects are only two aspects that have not reached the indicator of success. This is because students are still embarrassed to argue or put forward ideas, questions or spoken because of shame and fear of missteps in delivering it, has not been able to do cooperation between members of the group well.

The results of observation during the learning took place learners began to pay attention to the explanation of the teacher. And in writing descriptive text some learners already understand. As well as the courage of learners to ask and express opinions began to emerge. Although the learner in the delivery with shame.

\section{3) Students Responses}

Students responses in the learning are collected based on a response questionnaire given at the end of cycle II. Based on questionnaires filled with students, $7 \%$ stated strongly agree, 22\% agreed, 35\% hesitant and 35\% disagreed. Based on the observation result during the implementation of action of cycle II, obtained a significant development, both in terms of process and learning outcomes. Overall, it can be concluded that the student has reached the determined KKM score.

\section{B. Student Error In Descriptive Text Writing}

Based on the results of the research, the errors are often made by the students of class X SMK Triatma Jaya Dalung in writing descriptive text paragraphs among them in terms of creativity of topic development. The content of paragraphs of text is appropriate to the topic, but the development of ideas is still not appropriate. This is evident from the development of explanatory sentences. At the beginning of the sentence the student has made the contents of the paragraph correctly, but entering the explanation of the students often deviated from the topic. This explanatory sentence is less in line with the main sentence the author conveyed at the beginning of the descriptive paragraph.

In the case of an organization, which includes descriptive structures, it is structured as appropriate descriptive structure. However, the descriptive structure is still a little unorganized. In the descriptive text there is already a section of conclusions. However, the conclusions conveyed were less in line with the initial statement submitted by the students. The descriptive structure in the paragraph already exists, but still not well organized.

In terms of vocabulary selection, language usage, and mechanical aspects, the descriptive has several flaws. In terms of vocabulary selection for example there are some inappropriate vocabulary use. There is still a mistake in the formation of vocabulary, as for example the word importance. The big words that coincide with the word importance are less precise, it would be more appropriate if the big word is omitted. In terms of language use, the article still has errors in terms of the structure of the sentence is less clear and the use of sentences is also less precise. This can be seen from the less unified sentence one with another sentence. In terms of mechanical aspects, there are still many errors in the use of punctuation. An example is seen in the use of coma. The error that occurs is the use of commas that should be combined with words written using spaces. Another comma-line misuse error, that is, the use of a comma is behind the word but and therefore. Another mechanical aspect mistake is the use of a hyphen so that the word is interconnected, so it should be used as an intracalimatic word.

\section{Improved Instruction-Based Teaching}

Management of learning with the right PBI model can improve the skills of writing paragraphs of descriptive text of students of Class X SMK Triatma Jaya Dalung. Improved understanding of reading and learning activities of students is also supported by the response of students who agree with the application of the PBI model on learning to write paragraphs of descriptive text. Based on the questionnaires filled with the students, the average student response is agreed. There are several reasons why students agree with the application of the PBI model. First, the PBI model is more fun in learning to write descriptive text paragraphs. The activity of pouring thoughts / ideas in the form of descriptive text paragraphs is stimulated by the problems that exist in the reading. Secondly, the PBI model is more effective in writing descriptive text paragraphs because the problems that exist in reading are easier and inspire students in generating ideas. Third, the PBI model can enhance student creativity. This behavior can be observed from the writings of students, especially writing skills topic sentences, explanatory sentences, choice of words, and writing techniques. Fourth, the PBI model can increase students' criticality when writing descriptive text paragraphs. They are pouring ideas based on the problems they have on reading. In writing descriptive text paragraphs, students take the thinking process to analyze, synthesize, and evaluate problems. The process of thinking when students write descriptive text paragraphs is to increase students' criticality to the problems at hand. Sixth, the PBI model can motivate students in writing. They are motivated to solve problems, departing from interesting issues that they need to address and address, such as describing about someone or things in our life. 


\section{CONCLUDE}

1) Application of learning with PBI model can also increase student learning activity. Management of learning with PBI models that can improve students' descriptive paragraph writing skills are: (1) students who are often noisy moved to the front seat by teachers to avoid noise in the classroom; (2) students are given the opportunity to prepare learning tools before teachers start learning; (3) students are given emphasis to understand the learning objectives; (4) students pay attention to examples of topic sentences, explanatory sentences, and paragraph descriptive paragraphs made by teachers; (5) students are emphasized to listen to the teacher's explanation of the steps to write descriptive paragraphs based on the problem; and (6) students are given the assertion that the making of descriptive paragraphs based on the problem should be initiated by intensive reading.

2) The mistakes often made by the students of class $\mathrm{X}$ of SMK Triatma Jaya Dalung in writing descriptive text paragraph among them in terms of creativity of topic development, in terms of organization that includes descriptive structure and in terms of vocabulary selection, language use, and mechanical aspects, descriptive paragraph it has some drawbacks.

3) Management of learning with the right PBI model can improve the skills of writing paragraphs of descriptive text of students of Class X SMK Triatma Jaya Dalung. First, the PBI model is more fun in learning to write descriptive text paragraphs. Secondly, the PBI model is more effective in writing descriptive text paragraphs because the problems that exist in reading are easier and inspire students in generating ideas. Third, the PBI model can enhance student creativity.

\section{III.CONCLUSION}

The results showed that the learning of writing descriptive text using instruction-based learning method is more effective than writing learning without using instruction-based instruction method. The results of these studies have practical implications. In practical terms, the results of this study prove that the use of instruction-based instructional methods in writing descriptive writing lessons is more effective than learning to write without using instruction-based learning method so that strategy can be used on learning writing descriptive text. Teachers of SMK Triatma Jaya Dalung can use instruction-based instructional method in learning descriptive text writing to improve the skills of writing descriptive text on students.
A massive gratitude is conveyed to the Department of linguistics at the Universities of Warmadewa Denpasar on the occasion and also the support of this research, so that it can be one form of contribution for the institution. Acknowledgments, also do not forget, I address to my family who have given support that I can not mention one by one, so that this paper can be completed in a timely manner.

\section{RFERENCE}

Arikunto, S. (2013). Prosedur Penelitian: Suatu Pendekatan Praktik. In Jakarta. Rineka Cipta.

Ayu, I., \& Darmayanti, M. (2014). Peningkatan keterampilan menulis paragraf argumentasi melalui pembelajaran berbasis masalah. Jurnal Pendidikan Dan Pengajaran, 2-3(Jilid 47), 145-154.

Firdaus, H., Herpratiwi, H., \& Rosidin, U. (2015). Evaluasi Pemanfaatan Sumber Belajar Berbasis Teknologi Informasi Dan Komunikasi. Jurnal Teknologi Informasi Komunikasi Pendidikan, 3(1), 1-16. Retrieved from http://jurnal.fkip.unila.ac.id/ index.php/JTP/article/view/7429

Nurgiyantono, B., Gunawan, \& Marzuki. (2009). Statistik terapan untuk penelitian ilmu-ilmu sosial.

Nurhadi. (2004). Kurikulum 2004 Pertanyaan dan Jawaban. In Jakarta. Grasindo.

Tarigan, H. G. (2008). Menulis sebagai Suatu Keterampilan Berbahasa. In Bandung. Angkasa.

Trianto. (2007). Model-Model Pembelajaran Inovatif Berorientasi Konstrutivistik. In Jakarta. Prestasi Pustaka.

\section{ACKNOWLEDGEMENT}

